\title{
THE EFFECT OF THE NON-PHYSICAL WORK ENVIRONMENT AND JOB INSECURITY ON THE PERFORMANCE OF OUTSOURCING EMPLOYEE BUSINESS SUPPORT THROUGH THE MOTIVATION AS INTERVENING VARIABLE AT PT. TELEKOMUNIKASI SELULAR BRANCH MEDAN
}

\author{
Nuri Aslami \\ Master of Management \\ Faculty of Economics and Business \\ Universitas Sumatera Utara \\ Medan, Indonesia \\ Nurie.asy@gmail.com
}

\author{
Sitti Raha Agoes Salim \\ Departement of Management \\ Faculty of Economic and Business \\ Universitas Sumatera Utara \\ Medan, Indonesia \\ Indonesiasittisalim@yahoo.com
}

\author{
Yeni Absah \\ Departement of Management \\ Faculty of Economic and Business \\ Universitas Sumatera Utara \\ Medan, Indonesia
}

\begin{abstract}
PT. Telekomunikasi Selular is a company engaged in the mobile telecommunications business industry in Indonesia. The company uses outsourcing employees for several positions, one of which is the administrative position to support of the company activities. The purpose of this research is to 1) analyze the influence of non-physical work environment on the motivation of Outsourcing Employee business support at PT. Telekomunikasi Selular Branch Medan; 2) analyze the influence of job security on the motivation of Outsourcing Employee business support at PT. Telekomunikasi Selular Branch Medan; 3) analyze the influence of non-physical work environment on the performance of Outsourcing Employee business support at PT. Telekomunikasi Selular Branch Medan; 4) analyze the influence of job security on the performance of Outsourcing Employee business support at PT. Telekomunikasi Selular Branch Medan; 5) analyze the influence of motivation on the performance of Outsourcing Employee business support at PT. Telekomunikasi Selular Branch Medan; 6) analyze the influence of non-physical work environment on the performance of Outsourcing Employee business support through motivation as intervening variable at PT. Telekomunikasi Selular Branch Medan; 7) analyze the influence of job security on the performance of Outsourcing Employee business support through motivation as intervening variable at PT. Telekomunikasi Selular Branch Medan. Population in this research is Outsourcing Employee PT. Telkomsel Medan Branch which has 132 people with a sample of 99 people. The engineering samples used in this research is Simple Random Sampling technique. Data analysis method used is path analysis. The results showed that 1) Non-physical work environment has a positive and significant impact on the motivation of Outsourcing Employee business support at PT.
\end{abstract}

Telkomsel Branch Medan. 2) Job Insecurity has a negative and significant impact on the motivation of Outsourcing Employee business support at PT. Telkomsel Branch Medan. 3) Nonphysical work environment has a positive and significant impact on the performance of Outsourcing Employee business support at PT. Telkomsel Branch Medan. 4) Job Insecurity has a negative and significant impact the performance of Outsourcing Employee business support at PT. Telkomsel Branch Medan. 5) Motivation has a positive and significant impact on the performance of Outsourcing Employee business support at PT. Telkomsel Branch Medan. 6) Non-physical work environment has a positive and significant impact on the performance of Outsourcing Employee business support through work motivation at PT. Telkomsel Branch Medan. 7) Job insecurity has a negative and significant impact on the performance of Outsourcing Employee business support through work motivation at PT. Telkomsel Branch Medan.

Keywords- Non-physical work environment, job insecurity, motivation and the performance of employees outsourcing business support.

\section{INTRODUCTION}

Business competitiveness is the case today cause changes so fast in a business that requires companies to be able to adapt, have endurance, able to change direction quickly, and concentrate to customers. One of the business strategy that many companies do is to hand the processes that are not a core competence the company to the third party. 
The rise of the system outsourcing would have a significant impact on the employment relationship between the employee and the company management. Given this, the emergence intensity job insecurity becomes higher felt by employees. Job insecurity can affect the motivation of employees of outsourcing because they feel insecure, one of which is only the status of the contract. In general, a high motivation associated with high performance, and vice versa. An individual's performance relates to the ability and desire have, because there are personal and environmental factors that affect work performance.

At PT. Telkomsel Medan, outsourcing employees to part Business Support obtained from company PT. Outsourcing Kinarya Mandiri (KAM) as a provider of employment. The contract system is applied to the 2014 run for one year once. While in 2015, the regulations regarding the applicable contract period PT. KAM turned into two years. Even so, many of the employees outsourced who resigned or was terminated before the expiration of the contract. This is due to the resignation of employees and outsourcing companies are not penalized by the employment service. Turnover employees outsourced at PT. Telkomsel Medan itself is still very high. It can be seen from Table 1 below:

Table 1. Data Turnover Outsourcing Employee of Business Support in PT. Cellular Telecommunications Medan Branch

\begin{tabular}{ccc}
\hline \multirow{2}{*}{ Year } & \multicolumn{2}{c}{ Number of Employees Outsourcing } \\
\cline { 2 - 3 } & The Beginning & Of End \\
\hline 2014 & 211 & 205 \\
\hline 2015 & 214 & 171 \\
\hline 2016 & 171 & 132
\end{tabular}

Source: The Office of Human Resources PT. Kinarya Alih Daya Mandiri at $2014-2016$

The problems that arise related to non-physical work environment is the lack of attention of superiors to situations and conditions that slow down the work employees outsourced. In addition, the cooperative relationship among employees Outsourcing with permanent employees less, causing a buildup of work to do. The slow process of file administrative charges on division finance to be one result.

For employees of outsourcing, job insecurity that is felt to be the inevitable. Job insecurity can affect the motivation of employees of outsourcing because they feel insecure, one of which is only the status of the contract. Worrying will lose their jobs at any time causing unease for outsourced employees. So will decrease the performance of the employee. In addition, regulatory changes often occur in the PT. Telkomsel Medan. Causing a state of uncomfortable and ambiguous experienced by employees of outsourcing.

Policies regarding the reduction of overtime hours are also one form of insecure at Telkomsel Medan. For employees of outsourcing, time overtime which was not limited to only 22 hours a month. These circumstances make employees outsourcing feel worried about the reduced benefit that will be received. Though often employees outsourced still have to work outside working hours that have been determined over 22 hours a month. The company policy that employees be felt powerless to deal with the conditions and situations that happened because he did not get a good socialization of the enterprise on a consistent policy.

These things cause the performance of employees outsourced in PT. Telkomsel Medan considered still not optimal. This is evident from the complaints of some employees remain in force as a user of the results of the outsourcing employee. Both in terms of precision, accuracy and timeliness in settlement. Additionally, in part of outsourced employees often neglect the work that should be their responsibility. As data partner companies lacking updates, completeness file bills that often are lacking so that the file must be returneddireturn, circulation the old file that causes the beam period expired, the use of hours of rest for too long so as not standby work, and so on.

The following is a table showing the percentage of absenteeism level data outsourcing PT. Telkomsel Medan.

Table 2. Attendance to Outsourcing Employee of Business Support at PT. Cellular Telecommunications Branch Medan

\begin{tabular}{ccccccc}
\hline \multirow{2}{*}{ Years } & \multicolumn{2}{c}{ Too Late } & \multicolumn{2}{c}{ Sick } & \multicolumn{2}{c}{ Permit } \\
\cline { 2 - 7 } & Amount & $\%$ & Amount & \% & Amount & \% \\
\hline 2014 & 120 & 56,87 & 52 & 24,64 & 39 & 18,48 \\
\hline 2015 & 131 & 61,21 & 57 & 26,64 & 26 & 12,15 \\
\hline 2016 & 114 & 64,04 & 43 & 24,16 & 21 & 11,80 \\
\hline
\end{tabular}

Source: The office of Human Resources PT. Kinarya Alih Daya Mandiri (Processed Data)

At the data in Table 2 can be seen that from 2014 until 2016, the level of absenteeism. Outsourcing is still high. The percentage rate of tardiness, sick and permits showed an increase from year to year. This suggests that a lack of motivation to work which also shows that employees feel disappointed at the company, so that they exhibit a negative work behaviors such as: late for work, miss work, delaying the work, even the decision to leave the company.

Based on the results of pre-survey conducted based on interviews with seven employees outsourcing in the office PT. Telkomsel Medan, this problem occurs because no clear job description that is given to employees of outsourcing. Often from employees outsourcing feel their workload is too high because it must work outside of work or responsibilities outsourced employees. Moreover, the absence of severe sanctions for employees outsourced who make mistakes is also a trigger negligence work. The biggest concern experienced by employees of outsourcing is the termination of contracts that can happen at any time.

\section{BASIC THEORY}

\section{A. Non-Physical Of Work Environment}

The non-physical work environment is all circumstances that occur relating to labor relations, good relations with superiors and co-workers relationships, or relationships with subordinates [1]. Moreover, psychic working environment defined as something that concerns the psychological aspect of 
the working environment. Based on these notions, it can be said that the non-physical work environment is a work environment that can not be captured by the human senses, but the non-physical work environment can be felt by the workers through relationships with fellow workers and superiors.

\section{1) Relationship with boss}

Leadership is a relationship that affects the behavior of others in order to work better fits the organization's objectives. The above theory is supported by the other theory regarding the non-physical work environment, adding that gives a fair and objective treatment of employees by implementing a system of reward and punishment will show the shape of the company's attention on the performance of the employee. The indicator for the relationship with superiors, namely: harmony, trust, clarity of task and reward systems [2].

2) Relationship with boss

Management must create inter-personal relationships within the company and with a high sense of family. For example, by doing activities together. A good relationship between employees will assist the company in creating a harmonious working atmosphere and conducive in order to achieve the goals set. The indicator relationships with colleagues, namely: communication, teamwork, and a sense of caring.

\section{B. Job Insecurity}

Job insecurity is the helplessness of a person in maintaining the desired continuity in working conditions threatened 3]. Job insecurity is defined as a state of insecurity caused by the threats to the survival of his work. Job insecurity has negative consequences to the attitude of the organization's work, such as the deterioration of working conditions, lack of career opportunities, salary reduction, development and in some cases may damage relations with the workers' organizations [4].

As for the dimensions or components that make job insecurity [5]:

1) In the aspect of the job, for example, lack of promotion, no increases in wages, and setting a schedule that varies

2) Possible changes to the sustainability of the work, for example, such as the emergence of the level of concern was fired and also the level of concern loss of dignity and worth.

3) Possible changes in the level of the working environment, such as the level of the threat of job loss from the company's internal and external environment, the regulatory changes within the company and also the high level of competition. \environment.

\section{Work Motivation}

The motivation comes from the word motivation, which means "move." Motivation is the result of a process that is internal or external to an individual, causing enthusiasm and persistence in carrying out certain activities [6]. Moreover, motivation is a process that explains the intensity, direction and persistence of an individual to achieve the goal [7]. In conjunction with the working environment, motivation is defined as conditions that affect evoke, directing and maintaining behavior associated with the work environment.
Based on some existing definitions above, it can be concluded that motivation is the urge someone to do a job [8].

States that the factors that affect the motivation of an employee there that are internal and external [9].

1) Internal factors. That are internal factors (motivator factor), among others: responsibility, work itself, achievements, recognition of others, the possibility of development and progress.

2) External Factors that affect one's motivation is often called hygiene factors, among others: the administration and company policies, salary, interpersonal relations, and working conditions.

\section{Employee Performance}

Performance is basically what is done or not done by employees [10]. The performance of employees as a result of the quality and quantity of work that can be achieved in performing the duties of an employee in accordance with the responsibilities given to him. Based on the definition of the employee's performance, it can be concluded that the employee's performance is the quality and quantity of an individual or group work to achieve the purpose of the work [11].

The performance of public employees include:

1) Quantities and results: the achievement of job description a given can be measured absolute, in percentage or index.

2) Quality and results: the quality is relative, so it is not easily measured and depends on individual taste. The quality can be felt, seen or touched.

3) Time and speed of results: each task execution always takes as entered. Time is a resource that is expensive, because he is limited, can not be stored or delayed.

4) The presence or absence: the level of attendance and punctuality in the work can be one of the factors to look at the motivation of employees in the work.

5) Interoperability: each employee must be able to collaborate with co-workers and have the initiative in helping co-workers in order to create a comfortable working atmosphere.

6) The taste can be trusted: employees who work well will be trusted by his colleagues to be able to complete the next job. 


\section{E. Conceptual Framework}

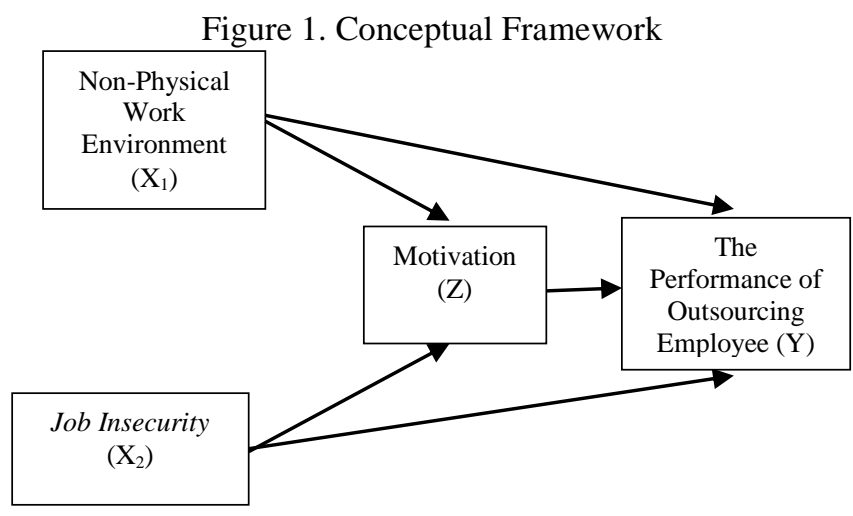

F. Hypothesis

- $\quad \mathrm{H} 1$ = Variable non-physical work environment positive and significant effect on work motivation Outsourcing Employee Business Support.

- $\quad \mathrm{H} 2=$ Variable job insecurity significant negative effect on work motivation Outsourcing Employee Business Support.

- $\quad \mathrm{H} 3$ = Variable non-physical work environment positive and significant effect on employee performance variables Outsourcing Business Support.

- $\quad \mathrm{H} 4$ = Variable job insecurity significant negative effect on employee performance variables Outsourcing Business Support.

- $\quad$ H5 = variable work motivation positive and significant impact on employee performance variables Outsourcing Business Support.

- $\quad$ H6 = Variable non-physical work environment positive and significant effect on the variable Employee performance Outsourcing Business Support through motivation.

- $\quad \mathrm{H} 7=$ Variable job insecurity significant negative effect on the variable Employee performance Outsourcing Business Support through motivation.

\section{THE METHODS}

Before you begin to format your paper, first write and save the content as a separate text file. Keep your text and graphic files separate until after the text has been formatted and styled. Do not use hard tabs, and limit use of hard returns to only one return at the end of a paragraph. Do not add any kind of pagination anywhere in the paper. Do not number text headsthe template will do that for you.

Type of research used in this research is using associative research with a quantitative approach. This research was conducted at the office of PT. Telkomsel Medan Branch. The study was planned months from April to August 2017.

In this study, there are three variables of the study are:

1. The variable independent (free) in this research that Non-Physical Work Environment $\left(\mathrm{X}_{1}\right)$ and Job insecurity $\left(\mathrm{X}_{2}\right)$.
Non-Physical Working Environment $\left(\mathrm{X}_{1}\right)$ are all circumstances that occur relating to the good working relationship with the relations with superiors and subordinates as well as relationships with colleagues. From the definition above, the dimension is the relationship with the boss and relationships with coworkers.

Job insecurity $\left(\mathrm{X}_{2}\right)$ is the helplessness of a person in maintaining the desired continuity in working conditions threatened. The dimensions contained in the work environment variables are:

a. Aspects of the work, this dimension indicator is the lack of promotion, no increases in wages, and setting a schedule change.

b. The significance of the entire work, indicators of this dimension is the emergence of the level of concern was fired and also the level of concern loss of dignity and worth.

c. The possibility of adverse changes in the work environment, indicators of this dimension is the level of the threat of job loss from the company's internal and external environment, the regulatory changes within the company and also the high level of competition.

2. The variable dependent (dependent) in this research is employee performance (Y).

Employee Performance (Y) is the result of the quality and quantity of work that can be achieved in performing the duties of an employee in accordance with the responsibilities given to him. The dimensions of the work performance variables, namely:

a. Quality is the level achieved by the process or the results obtained in an activity close to perfection. Measured by three indicators, namely: provision of employment, do the job thoroughly, and finish the job neatly.

b. Quantities work includes the output should be noted not only the output but also quick routine to finish the work "extra." Measured by two indicators: work capacity and job targets.

3. Intervening variables in this study is the motivation (Z).

Motivation ( $\mathrm{Z}$ ) is the thrust of the individual that explains the intensity, direction, and persistence of an employee to achieve the goal. The dimensions of the motivational variables, namely:

a. Internal indicators in this dimension that responsibility, advancement, and the work itself.

b. External indicators in this dimension, namely working conditions, salary, compensation, job security, and employment status.

Researchers used a Likert scale to measure each variable. Determination of value is based on Likert Scale respondents is the sum of the value scale given in each of the answers on the 
questionnaire. The population used in this research is employees outsourced of PT. Telkomsel Medan Branch, amounting to 132 people. The number of samples in this study was 99 respondents obtained from simple random sampling technique.

Data used in this study researchers were:

\section{a. Primary data:}

This data is gathered from primary source or the respondent by asking questions related to the non-physical work environment, job insecurity, motivation and performance of employees of outsourced business support PT. Cellular Telecommunications Branch Medan.

\section{b. Secondary data}

Secondary data obtained by researchers is data collected from archived data Human Resources Division Outsourcing PT. Kinarya Alih Daya Mandiri since 2014 through 2016.

\section{TECHNICAL DATA ANALYSIS}

After the text edit has been completed, the paper is ready for the template. Duplicate the template file by using the Save As command, and use the naming convention prescribed by your conference for the name of your paper. In this newly created file, highlight all of the contents and import your prepared text file. You are now ready to style your paper; use the scroll down window on the left of the MS Word Formatting toolbar.

\section{Test Validity}

Validity test used to determine if there are any questions on the questionnaire invalid because it was considered irrelevant. Valid test is determined by comparing the value of $r$ count (table corrected item-total correlation) with $\mathrm{r}$ table (table product moment to 0.05 ) for the degree of freedom (df) $=n k$ [12].

\section{Test Reliability}

Test reliability is an index indicating the degree to which a tool used to measure trustworthy or reliable. The questions which were declared invalid in the validity of the test will be determined if the criteria of reliability with value Cronbach's Alpha $\geq 0.60$ then the question is reliable.

\section{Classical Assumption Test}

Testing classic assumption will be made up of:

a. Residual Normality Test

b. Test heterokedastisitas

c. Test Multicollinearity

\section{Descriptive Analysis Method}

Descriptive analysis is the analysis used in a way to formulate and interpret the data so that it can provide a clear picture through the collection, compilation, and can analyze the data so it can be a general overview company to be researched [13].

\section{Path Analysis Method (Path Analysis)}

Is used to analyze the relationship between variables, with the aim to determine the effect, directly or indirectly, a set of independent variables (exogenous) to the dependent variable (endogenous) [14].

Figure 2 Sub-Model I Path Analysis for Structural Equation

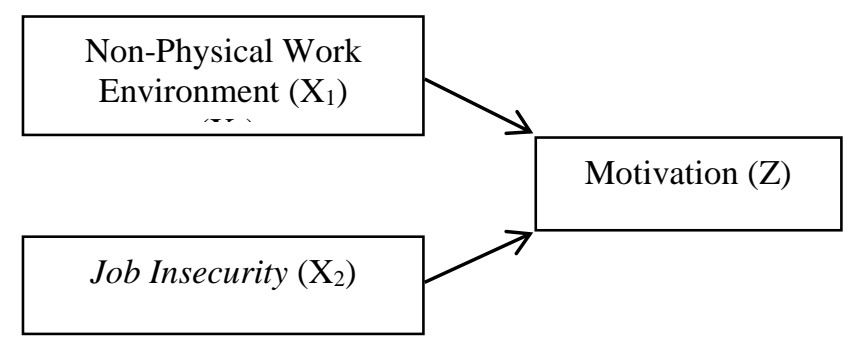

Figure 3 Sub-Model II Path Analysis for Structural Equation

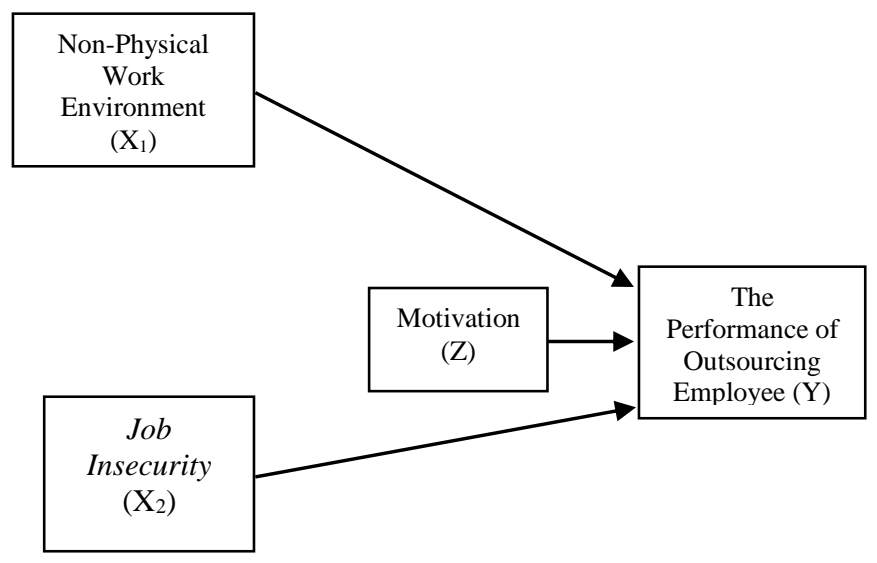

Where:

$\mathrm{X} 1=$ Score Non-Physical Work Environment Indicators

$\mathrm{X} 2=$ Score Indicator Job Insecurity

$\mathrm{Z}=$ Motivation Indicator Score

$\mathrm{Y}=$ Score Employee Performance Indicator

Diagram of lines in the image above consists of two structural equation, where $\mathrm{X} 1$ and $\mathrm{X} 2$ are the exogenous variables, while $\mathrm{Z}$ and $\mathrm{Y}$ are endogenous variables. Equation structural can be structured as follows:

$$
\begin{gathered}
\mathrm{Z}=\mathrm{a}+\mathrm{b} 1 \mathrm{X} 1+\mathrm{b} 2 \mathrm{X} 2+\mathrm{e} 1 \\
\mathrm{Y}=\mathrm{a}+\mathrm{b} 3 \mathrm{X} 1+\mathrm{b} 4 \mathrm{X} 2+\mathrm{b} 5 \mathrm{Z}+\mathrm{e} 2
\end{gathered}
$$

\section{RESULTS AND DISCUSSION}

1. Validity and Reliability Test

Validity test results throughout the questions this study declared invalid. Reliability testing which states that the instrument variables in this study is reliable.
2. Classical Assumption Test
a. Normality Test 
Normality test results are as follows:

Figure 4. PP-Plot Graphs

Histogram

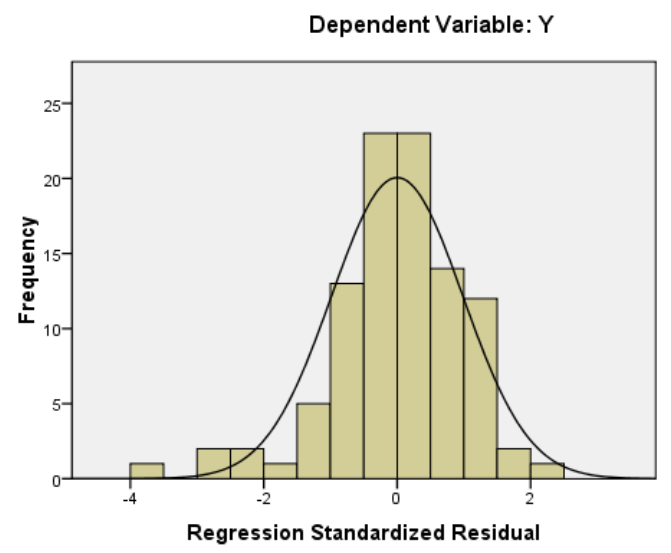

Mean $=1.97 E-16$
Std. Dev. $=0.985$
$N=99$

The histogram above results showed that the distribution histogram of the data residuals follows a normal distribution pattern distribution histogram which approximates the shape of a bell.

b. Multicollinearity Test

Multicollinearity test results can be seen in the following table:

Table 3. Results Multicollinearity Test

\begin{tabular}{llll}
\hline \multicolumn{2}{c}{ Coefficients } & \multicolumn{2}{l}{ collinearity Statistics } \\
\cline { 2 - 4 } Model & & Tolerance & VIF \\
\hline 1 & \multicolumn{2}{c}{ (Constant) } & \\
\cline { 2 - 4 } & $\begin{array}{l}\text { Non- } \\
\text { Physical Work } \\
\text { Environment }\end{array}$ & .990 & 1.010 \\
\cline { 2 - 4 } & $\begin{array}{c}\text { Job } \\
\text { Insecurity }\end{array}$ & .757 & 1,320 \\
\cline { 2 - 4 } & Motivation & .764 & 1,309 \\
\hline
\end{tabular}

a. Dependent Variable:

Employee Performance

Source: Research Data Processing (2016)

Table 3 provides information that tolerance values $>0.1$ means that there were no symptoms of multicollinearity. Similarly, VIF (Variance Inflation Factors) $<5.0$ means no symptoms multikolinieritas.

\section{c. Heterokedastisitas Test} table:

Heterokedastisitas test results can be seen in the following
Figure 5. Scatterplot Graph

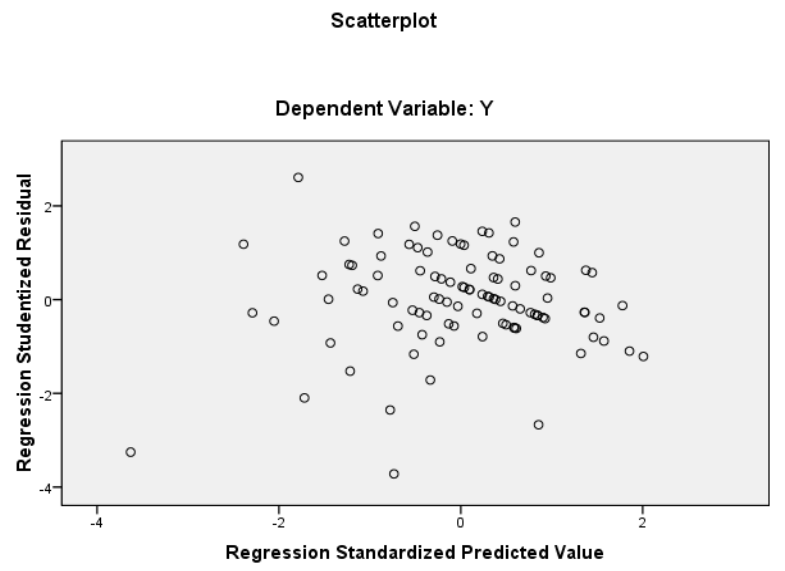

Figure 5 provides that the distribution of residual information is homokedastisitas wherein the data on the graph shows the distribution of the data residual evenly all over the place without forming a specific pattern. Thus it can be said that this model is a good model and free from problems heterokedastisitas.

\section{Path Analysis}

Working Environment Influence Analysis of Non-Physical $\left(\mathrm{X}_{1}\right)$ and Job Insecurity $\left(\mathrm{X}_{2}\right)$ the Employee Performance Outsourcing (Y) through motivation $(\mathrm{Z})$ - Testing Sub Model 1.

Table 4. Model Summary Sub Model 1

\begin{tabular}{|c|c|c|c|c|c|c|c|c|c|c|}
\hline \multicolumn{11}{|c|}{ Model Summary ${ }^{\mathrm{b}}$} \\
\hline \multirow{2}{*}{ Model } & \multirow[b]{2}{*}{$\mathrm{R}$} & \multirow{2}{*}{$\begin{array}{c}\mathrm{R} \\
\text { Square }\end{array}$} & \multirow{2}{*}{$\begin{array}{c}\text { Adjusted } \\
\text { R } \\
\text { Square }\end{array}$} & \multirow{2}{*}{$\begin{array}{c}\text { Std. } \\
\text { Error of } \\
\text { the } \\
\text { Estimate }\end{array}$} & \multicolumn{5}{|c|}{ Change Statistics } & \multirow{2}{*}{$\begin{array}{l}\text { Durbin- } \\
\text { Watson }\end{array}$} \\
\hline & & & & & $\begin{array}{c}\mathrm{R} \\
\text { Square } \\
\text { Change }\end{array}$ & $\begin{array}{c}\mathrm{F} \\
\text { Change }\end{array}$ & f1 & $\mathrm{f} 2$ & $\begin{array}{c}\text { Sig. F } \\
\text { Change }\end{array}$ & \\
\hline 1 & $.486^{\mathrm{a}}$ & .236 & .220 & 2.17609 & .236 & 14.824 & 2 & 96 & .000 & 1.598 \\
\hline \multicolumn{11}{|c|}{ a. Predictors: (Constant), Non-physical work environment , Job Insecurity } \\
\hline \multicolumn{11}{|c|}{ b. Dependent Variable: Motivation } \\
\hline
\end{tabular}

Source: Research Data Processing (2016)

Table 4 gives information about the predictive ability of the model study sub-models 1 . Where the adjusted R-square value $\left(\mathrm{R}^{2}\right)$ of 0.220 means that the variable $\mathrm{X}_{1}$ (Non-Physical Work Environment) and $X_{2}$ (Job Insecurity) is able to explain $22 \%$ of the variance of the dependent variable $\mathrm{Z}$ (motivation). While the remaining $78 \%$ is explained by other factors not examined in this research model.

While the partial effect of the two independent variables $\left(\mathrm{X}_{1}\right.$ and $\left.\mathrm{X}_{2}\right)$ on the dependent variable $\mathrm{Z}$ can be explained by Table 5 below: 
Table 5. Coefficient Sub Model 1

\begin{tabular}{|c|c|c|c|c|c|c|}
\hline \multicolumn{7}{|c|}{ Coefficients } \\
\hline & \multirow[t]{2}{*}{ Model } & \multicolumn{2}{|c|}{$\begin{array}{l}\text { Unstandardized } \\
\text { Coefficients }\end{array}$} & \multirow{2}{*}{$\begin{array}{c}\begin{array}{c}\text { Standardized } \\
\text { Coefficients }\end{array} \\
\text { Beta }\end{array}$} & \multirow[t]{2}{*}{$\mathrm{T}$} & \multirow[t]{2}{*}{ Sig. } \\
\hline & & B & Std. Error & & & \\
\hline & (Constant) & 21.561 & 3.182 & & 6.776 & .000 \\
\hline 1 & $\begin{array}{c}\text { Lingkungan Kerja } \\
\text { Non Fisik }\end{array}$ & .015 & .041 & .033 & .371 & .002 \\
\hline & Job Insecurity & -.313 & .057 & -.488 & -5.443 & .000 \\
\hline
\end{tabular}

a. Dependent Variable: Motivation

\section{Source: Data Processing Researcher (2016)}

\section{$\mathrm{Z}=\mathbf{0 . 0 3 3} \mathrm{X}_{\text {to }} 10.488 \mathrm{X}_{2}+\mathrm{e}_{1}$}

Effect Analysis Working Environment Non-Physical $\left(\mathrm{X}_{1}\right)$ and Job Insecurity $\left(\mathrm{X}_{2}\right)$ the Employee Performance Outsourcing (Y) through Motivation (Z) - Testing Sub Model 2.

Table 6. Model Summary SubModel 2

\begin{tabular}{|c|c|c|c|c|c|c|c|c|c|c|}
\hline \multicolumn{11}{|c|}{ Model Summary ${ }^{b}$} \\
\hline \multirow[b]{2}{*}{ Model } & \multirow[b]{2}{*}{$\mathrm{R}$} & \multirow[b]{2}{*}{$\begin{array}{c}\mathrm{R} \\
\text { Square }\end{array}$} & \multirow[b]{2}{*}{$\begin{array}{l}\text { Adjusted } \\
\text { R Square }\end{array}$} & \multirow{2}{*}{$\begin{array}{l}\text { Std. } \\
\text { Error of } \\
\text { the } \\
\text { Estimate }\end{array}$} & \multicolumn{5}{|c|}{ Change Statistics } & \multirow[b]{2}{*}{$\begin{array}{l}\text { Durbin- } \\
\text { Watson }\end{array}$} \\
\hline & & & & & $\begin{array}{c}\mathrm{R} \\
\text { Square } \\
\text { Change }\end{array}$ & $\begin{array}{c}\mathrm{F} \\
\text { Change }\end{array}$ & df1 & df 2 & $\begin{array}{l}\text { Sig. F } \\
\text { Change }\end{array}$ & \\
\hline 1 & $.595^{\mathrm{a}}$ & .354 & .333 & 2.24792 & .354 & 17.340 & 3 & 95 & .000 & 1.280 \\
\hline \multicolumn{11}{|c|}{$\begin{array}{l}\text { a. Predictors: (Constant), Motivation, Non-physical work } \\
\text { environment, Job Insecurity }\end{array}$} \\
\hline
\end{tabular}

\section{Source: Data Processing Researcher (2016)}

The table provides information on the value of R-Square $\left(R^{2}\right)$ of 0.333 or it can be interpreted that the variable $X_{1}$ (the working environment of non-physical) and $\mathrm{X}_{2}$ (job insecurity)and the variable $\mathrm{Z}$ (motivation) was able to explain $33.3 \%$ variance of the dependent variable $\mathrm{Y}$ (the employee's performance). While the remaining $66.7 \%$ is explained by other factors not examined in this research model.

While the partial effect of variable $X_{1}, X_{2}$ and $Z$ on the dependent variable $Y$ can be explained by 4:17 the following table:
Table 7. Coefficient Sub Model 2

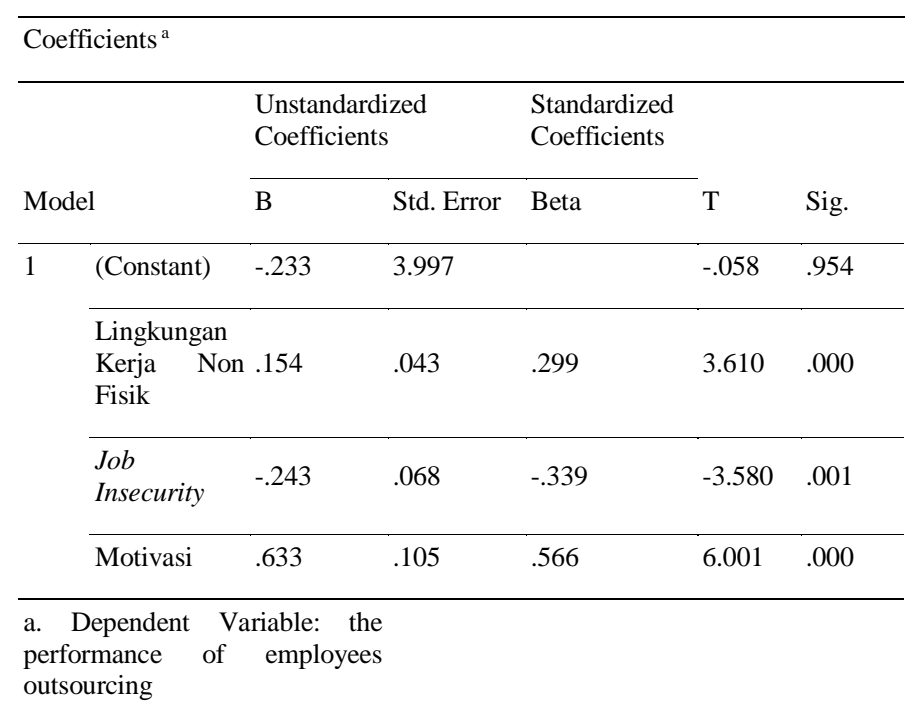

$$
Y=0.299 X_{\text {to }} 10.339 X_{2}+0.566 Z+e_{2}
$$

Table 7. Testing Hypotheses

\begin{tabular}{|c|c|c|c|c|}
\hline & Hypothesis & $\begin{array}{l}\text { Coefficient } \\
\text { Strip. }\end{array}$ & Sig & Conclusion \\
\hline $\mathrm{H}_{1}$ & $\begin{array}{l}\text { There is a positive and } \\
\text { significant influence of non- } \\
\text { physical work environment on } \\
\text { work motivation Outsourcing } \\
\text { Employee Business Support PT. } \\
\text { Telkomsel Medan Branch }\end{array}$ & 0,033 & 0,002 & Accepted \\
\hline $\mathrm{H}_{2}$ & $\begin{array}{l}\text { There is a negative and } \\
\text { significant impact of job } \\
\text { Insecurity on work motivation } \\
\text { Outsourcing Employee Business } \\
\text { Support PT. Telkomsel Medan } \\
\text { Branch }\end{array}$ & -0.488 & 0.000 & Accepted \\
\hline $\mathrm{H}_{3}$ & $\begin{array}{l}\text { are positive and significant } \\
\text { influence of non-physical work } \\
\text { environment on theperformance } \\
\text { of employees Outsourcing } \\
\text { Business Support PT. Telkomsel } \\
\text { Medan Branch }\end{array}$ & 0,299 & 0,000 & Accepted \\
\hline $\mathrm{H}_{4}$ & $\begin{array}{l}\text { There is a negative and } \\
\text { significant impact of job } \\
\text { Insecurity on theperformance of } \\
\text { employees Outsourcing Business } \\
\text { Support PT. Telkomsel Medan } \\
\text { Branch }\end{array}$ & -0.339 & 0.001 & Accepted \\
\hline $\mathrm{H}_{5}$ & $\begin{array}{l}\text { are positive and significant } \\
\text { influence of motivation on } \\
\text { employee } \\
\text { Putsourcing Business Support } \\
\text { PT. Telkomsel Medan Branch }\end{array}$ & 0.566 & 0.000 & Accepted \\
\hline
\end{tabular}


Table 7. Cont

are positive and significant influence of non-physical work environment on

$\mathrm{H}_{6} \quad$ employee performance through employee motivation Outsourcing Business Support PT.Telkomsel

There is a negative and significant impact of job Insecurity on employee

$\mathrm{H}_{7}$ performance through employee motivation Outsourcing Business Support PT. Telkomsel

\section{BASIC THEORY}

The results of research conducted hypothesis is able to answer the following conclusion:

1. There is a positive and significant influence of nonphysical work environment on employee motivation outsourcing business support PT. Telkomsel Medan Branch.

2. There is a negative and significant effect of job insecurity on employee motivation outsourcing business support PT. Telkomsel Medan Branch.

3. There is a positive and significant influence of nonphysical work environment on employee performance support outsourcing business PT. Telkomsel Medan Branch.

4. There is a negative and significant effect of job insecurity on employee performance support outsourcing business PT. Telkomsel Medan Branch.

5. There is a positive and significant influence of motivation on employee performance support outsourcing business PT. Telkomsel Medan Branch.

6. There is a positive and significant influence of nonphysical work environment on employee performance business outsourcing support through work motivation at PT. Telkomsel Medan Branch.
7. There is a negative and significant impact of job insecurity the performance of employees business outsourcing support through work motivation at PT. Telkomsel Medan Branch.

\section{REFERENCES}

[1] Sedarmayanti. 2001. Principles of Organizational Behavior. Bandung: Mandar Maju.

[2] Wursanto, Ignatius. 2009. Basic - Basic Science of Organization. Issue two. Yogyakarta: Andi.

[3] Nur Wening. 2005. The Influence of Job Insecurity as Impact of Restructuring on Job Satisfaction, Organizational Commitment and Intellectual Exit of Survivor. Journal of Performance. Volume 9, Number 2: 135-147.

[4] Sverke, M., Hellgreen, J., Naswall, K., Chirumbolo A., De Witte H., and Goslinga, S. 2002. Job Insecurity and Union Membership: European Union In The Wake of Flexible Production. Papers. Presented at the Tenth European Congress on Work and Organizational Psychology in Prague: Sweden.

[5] Chirumbolo, A. dan Hellgren, J. 2003. Individual and Organizational consequences of Job Insecurity: a European study. Economic and Industrial Democracy. 24, 215-238.

[6] Winardi, J. 2007. Motivation and Motivation in Management. Jakarta: King Gravindo.

[7] [Robbins, Stephen P. 2006. Organizational Behavior. Indonesia Edition. Index of Gramedia Group, Indonesia.

[8] Mangkunegara, A.A. Anwar Prabu. 2002. Evaluation of Human Resource Performance. First Print. Bandung: Refikaditama.

[9] Munandar A.S., 2001. Supervision, Role of Organizational Culture in Improving Performance of Company. Publisher: Division of Industrial Psychology and Faculty Organization Psychology UI, Jakarta: UI-Press.

[10] Mathis, R. L. And Jackson, J. H. 2006. Human Resource Management. The tenth print. (Diana Angelica Translation). Jakarta: Salemba Four.

[11] Mangkunegara, A.A. Anwar Prabu. 2004. Human Resource Management Company. First Print. Bandung: Teens Rosdakarya.

[12] Ghozali, Imam. 2011. Concept and Structural Equation Modeling Model with SPSS Program. Semarang: Diponegoro University Publishing Agency.

[13] Umar, Husayn. 2007. Research Design of MSDM and Employee Behavior. Jakarta: Raja Grafindo Persada.

[14] Riduwan. 2007. Method and Technique of Preparing Thesis. Bandung: Alfabeta. 